\title{
NID1 wt Allele
}

National Cancer Institute

\section{Source}

National Cancer Institute. NID1 wt Allele. NCI Thesaurus. Code C52485.

Human NID1 wild-type allele is located in the vicinity of $1 \mathrm{q} 43$ and is approximately $98 \mathrm{~kb}$ in length. This allele, which encodes nidogen-1 protein, is involved in the maintenance of the structure of the basement membrane. 